\title{
Crude fat, digestible protein and DL-carnitine levels in plant-based diets to Nile tilapia Oreochromis niloticus fingerlings
}

\author{
Samantha Chung ${ }^{1}$, Ricardo Yuji Sado $^{2}$ \& Álvaro José de Almeida Bicudo ${ }^{3}$ \\ ${ }^{1}$ Departamento de Pesca e Aquicultura, Universidade Federal Rural de Pernambuco, Recife, PE, Brasil \\ ${ }^{2}$ Universidade Tecnológica Federal do Paraná, Dois Vizinhos, PR, Brasil \\ ${ }^{3}$ Departamento de Zootecnia, Universidade Federal do Paraná, Palotina, PR, Brasil \\ Corresponding author: Álvaro José de Almeida Bicudo (ajabicudo@gmail.com)
}

\begin{abstract}
The chemical composition of diets is appointed as one responsible by different results of Lcarnitine supplementation in fish. This study determined the effects of digestible dietary protein (DP; 250 and $290 \mathrm{~g} \mathrm{~kg}^{-1}$ ) and crude fat (CF; 100 and $150 \mathrm{~g} \mathrm{~kg}^{-1}$ ) at levels of DL-carnitine supplementation (DLC; 0 and $1.0 \mathrm{~g}$ $\mathrm{kg}^{-1}$ ) in plant based-diets on growth and whole-body composition of Nile tilapia Oreochromis niloticus fingerlings $(1.55 \pm 0.03 \mathrm{~g})$. Fish were hand-fed for 74 days, three times per day until apparent satiation, in a completely randomized experimental design, $2 \times 2 \times 2$ factorial scheme $(\mathrm{n}=3)$. There was no effect $(P>0.05)$ of $\mathrm{DP}, \mathrm{CF}$, and DLC, or interactions, on growth performance. There was a significant interaction between $\mathrm{DP} \times \mathrm{CF}$; $\mathrm{DP} \times \mathrm{DLC}$ and DLC $\times \mathrm{CF}$ on feed efficiency. There was interaction $(P<0.05)$ between $\mathrm{CF} \times \mathrm{DLC}$ on feed intake (DFI). The DLC supplementation in $100 \mathrm{~g} \mathrm{~kg}^{-1} \mathrm{CF}$ diets increased DFI 5.6\% more than fish fed with the same fat level without DLC. Whole-body protein decreased significantly due to DLC supplementation in fish fed with $150 \mathrm{~g} \mathrm{~kg}^{-1} \mathrm{CF}$ diets. The level of DLC supplementation in Nile tilapia diets is variable and should consider the dietary CF levels, but not DP.
\end{abstract}

Keywords: Oreochromis niloticus; fingerlings; feed additive; fish nutrition; growth; lipid metabolism; aquaculture

\section{INTRODUCTION}

Dietary protein and lipids are the primary nutrients in aquafeeds used as energy sources by fish. However, protein also is the costliest macro-nutrient required in fish diets, and when excessively provided, it increases the environmental and economic losses in aquaculture. Moreover, animal protein sources used in formulating fish feeds are more expensive than vegetable protein sources. Consequently, the latter ones are used in high proportion to formulate diets for omnivorous species. Additionally, increase dietary lipids levels to spare protein as an energy source is a usual strategy to reduce the cost of formulation of fish diets, even for omnivorous species as Nile tilapia Oreochromis niloticus (Stickney \& Hardy, 1989; De Silva et al., 1991; Lim et al., 2011).

L-carnitine (LC) is a water-soluble quaternary amine synthesized endogenously from lysine and methionine and essential to mitochondrial $\beta$-oxidation of long-chain fatty acids (Bilinski \& Jonas, 1970). Plant ingredients are poor sources of LC (usually $0.5 \mathrm{mg} \mathrm{kg}^{-1}$ ) than animal protein sources that contain until $1.2 \mathrm{~g} \mathrm{~kg}^{-1}$ (Demarquoy et al., 2004; Harpaz, 2005). Thus, in a future perspective of the manufacture of aquafeeds with high levels of lipid and plant protein sources, it can be necessary to supplement LC in fish diets. L-carnitine supplementation can be especially necessary for young fish due to their limited endogenous production (Harpaz, 2005).

In recent years, several studies aimed to determine the level of LC supplementation to promote growth, reproduction features, and other physiological responses in different fish species (Lu et al., 2019; Rodrigues et al., 2019; Wang et al., 2019). However, results obtained until now remain controversial, even if related to the same species, such as in studies with African catfish (Clarias gariepinus) (Torreele et al., 1993; Ozório et al., 2001a,b; 2002; Naz et al., 2005), rainbow trout (Oncorhynchus mykiss) (Schuhmacher \& Gropp, 1998; Dikel et al., 2010; Jalali-Haji-Abadi et al., 2010; Selcuk et al., 2010; Ozório et al., 2012), and

Corresponding editor: Jesús Ponce-Palafox 
European seabass (Dicentrarchus labrax) (Santulli \& D'Amelio, 1986; Chatzifotis et al., 1995; Dias et al., 2001). This variability of effects from dietary LC supplementation in fish is attributed to different factors, among which the nutritional profile of diets is considered significant (Harpaz, 2005; Mohseni \& Ozório, 2014).

Thus, this study aimed to evaluate the effects of digestible dietary protein (DP), crude fat (CF) and DLcarnitine levels, and their interactions on growth, wholebody composition, and nutrient retention efficiency in Nile tilapia fingerlings fed high-fat plant-based diets.

\section{MATERIALS AND METHODS}

All experimental procedures were previously approved by the Ethics Committee on the Use of Animals of the Federal Rural University of Pernambuco (License $\left.\mathrm{N}^{\circ} 009 / 2013\right)$.

\section{Experimental diets}

Eight experimental diets were formulated to contains two levels of dietary DP (250 and $\left.290 \mathrm{~g} \mathrm{~kg}^{-1}\right), \mathrm{CF}(100$ and $\left.150 \mathrm{~g} \mathrm{~kg}^{-1}\right)$ and DL-carnitine - DLC $\left(0\right.$ and $\left.1 \mathrm{~g} \mathrm{~kg}^{-1}\right)$ levels (Table 1 ), in a completely randomized experimental design and $2 \times 2 \times 2$ factorial scheme $(n=3)$. Carnitine was added to diets as DLC hydrochloride (Sigma Aldrich ${ }^{\circledR}$ ) that contains $50 \%$ of the active biological form (LC). Digestible protein levels were established to supply the minimum nutritional requirement $\left(290 \mathrm{~g} \mathrm{~kg}^{-1}\right)$ for Nile tilapia (Oreochromis niloticus) according to NRC (2011) and below $250 \mathrm{~g}$ $\mathrm{kg}^{-1}$ to verify a possible protein-sparing effect by dietary supplementation of CF and DLC. Diets with low CF level $\left(100 \mathrm{~g} \mathrm{~kg}^{-1}\right)$ were formulated to supply the minimum digestible energy (DE) requirement (14.2 MJ $\mathrm{kg}^{-1}$ ) established by NRC (2011) for Nile tilapia. DE and DP of diets were calculated from data of apparent digestibility coefficients for Nile tilapia (Furuya et al., 2010). The chemical composition of all ingredients was determined before diet formulation. Ingredient's digestible energy (DE) and DP were estimated from apparent digestibility coefficients for Nile tilapia calculated from Furuya et al. (2010). Diet ingredients were grounded through a $1.0 \mathrm{~mm}$ sieve, mixed, moistened with distilled water $(30 \% \mathrm{v} / \mathrm{w})$, and pelleted $(2.0 \mathrm{~mm})$ in a mincer and then dried in a forced ventilation oven $\left(50^{\circ} \mathrm{C} ; 24 \mathrm{~h}\right)$. Dried pellets were hermetically packed in plastic bags and stored at $-4^{\circ} \mathrm{C}$ until use.

\section{Experimental system and animals}

Nile tilapia juveniles were provided by Companhia de Desenvolvimento do Vale do São Francisco e Parnaíba-
CODEVASF (Porto Real do Colégio, Alagoas, Brazil). Fish were acclimatized to experimental condition for seven days, feeding on a $40 \% \mathrm{CP}$ commercial diet.

Nile tilapia juveniles $(1.55 \pm 0.03 \mathrm{~g})$ were randomly stocked into 24 glass aquaria (75-L capacity, filled to 60-L, 18 fish per aquarium). Each aquarium was supplied with a flow rate of $0.7 \mathrm{~L} \mathrm{~min}^{-1}$, connected to a recirculation system, under continuous aeration, biological and mechanical filtration, temperature control, and 12:12 h light:dark photoperiod. Water oxygen (4.6 $\left.\pm 0.2 \mathrm{mg} \mathrm{L}^{-1}\right)$ and temperature $\left(27.0 \pm 0.2^{\circ} \mathrm{C}\right)$ were monitored daily with the aid of an oximeter (YSI model

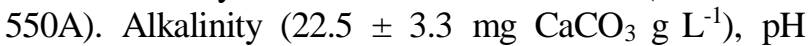
$(6.9 \pm 0.3)$, hardness $\left(91.3 \pm 19.4 \mathrm{mg} \mathrm{CaCO}_{3} \mathrm{~L}^{-1}\right)$, nitrite $\left(0.99 \pm 0.72 \mathrm{mg} \mathrm{L}^{-1}\right)$ and ammonia $\left(0.01 \pm 0.01 \mathrm{mg} \mathrm{L}^{-1}\right)$ were checked weekly using a commercial kit of the colorimetric methods (Alfakit, Florianopolis, SC, Brazil).

Fish were carefully hand-fed to apparent satiation daily (09:00, 13:00 and 17:00 h) for 74 days with the experimental diets. Feed intake was recorded for each experimental unit during the feeding trial. Fish were fasted for $24 \mathrm{~h}$, sedated in alcoholic benzocaine solution (50 $\mathrm{mg} \mathrm{L}^{-1}$ ), and weighted every 14 days to evaluate growth performance.

\section{Fish whole-body and diet chemical analyses}

Initially, a pooled sample of fish from the original population was previously fasted $(24 \mathrm{~h})$ and euthanized by anesthetic overdoses ( $0.5 \mathrm{~g} \mathrm{~L}^{-1}$ benzocaine) to determine whole-body composition. After 74 days, fish from each aquarium were fasted as described above, sedated ( $0.05 \mathrm{~g} \mathrm{~L}^{-1}$ benzocaine solution), weighed, and counted. Ten fish were randomly sampled from each aquarium, euthanized by anesthetic overdose as described before, grounded, and freeze $\left(-20^{\circ} \mathrm{C}\right)$ until chemical analysis.

The chemical composition of the ingredients, experimental diets, and fish samples was analyzed according to the procedures recommended by the Association of Official Analytical Chemists (AOAC, 1990). Moisture was determined by the gravimetric method in an oven at $105^{\circ} \mathrm{C}$ until constant weight. Ash content was determined using the gravimetric method in a muffle furnace at $550^{\circ} \mathrm{C}$ for $24 \mathrm{~h}$. Crude protein (N $\times 6.25$ ) was determined by the micro-Kjeldahl method, and crude fat was determined by the Soxhlet method. Crude fiber content was determined by acid/base digestion.

\section{Growth parameters}

The following growth parameters were calculated: weight gain $\left(\mathrm{WG}, \mathrm{g}\right.$ fish $\left.^{-1}\right)$ = final weight - initial weight; 


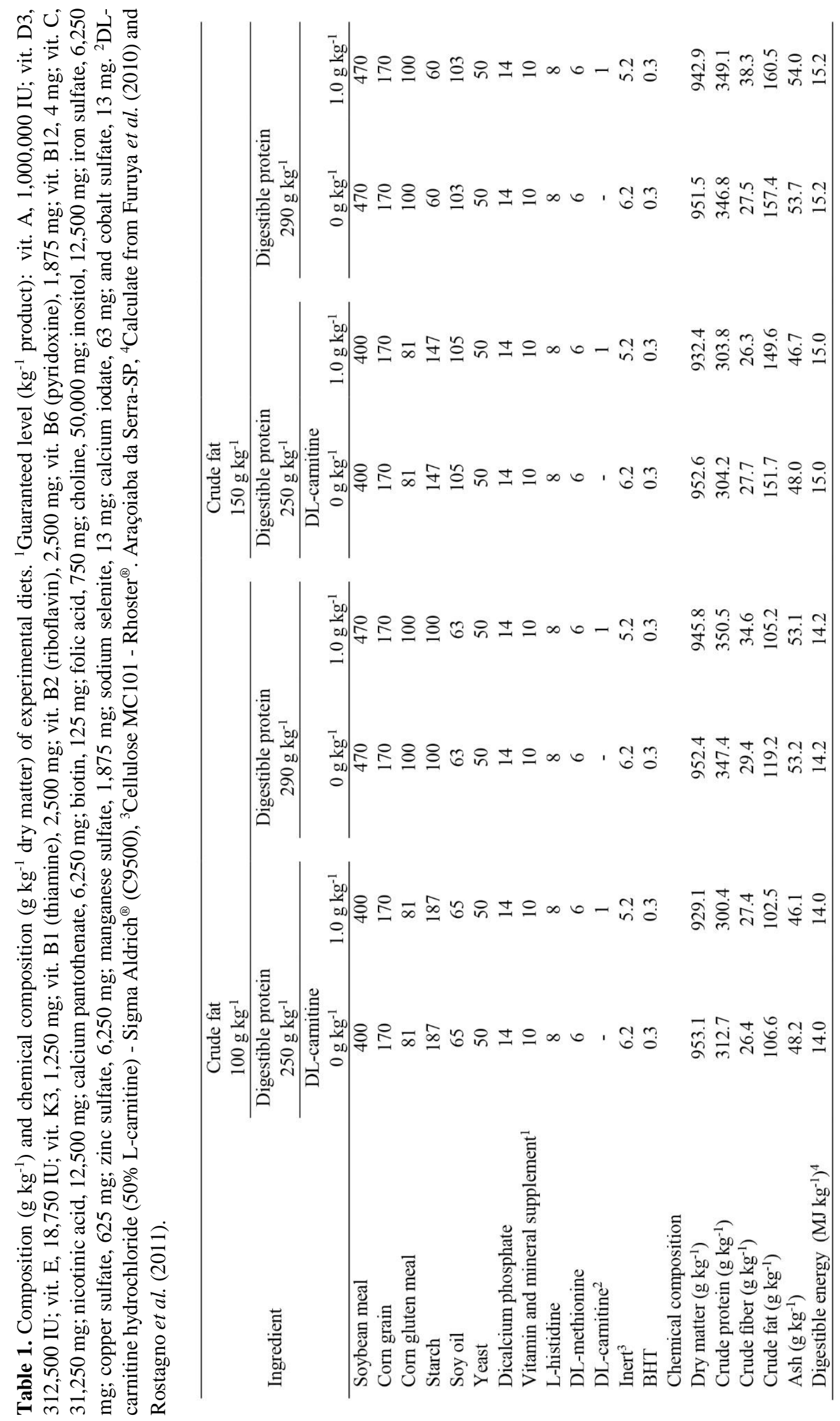


specific growth rate $\left(\mathrm{SGR}, \%\right.$ biomass $\left.\mathrm{d}^{-1}\right)=100 \times[(\mathrm{ln}$ final weight $-\ln$ initial weight) / days of the trial]; survival rate $($ SUR, \%) $=100 \times($ final number of fish each aquarium / initial number of fish); daily feed intake (DFI, \% biomass $\left.\mathrm{d}^{-1}\right)=$ \{feed intake $/[$ (final weight + initial weight) / 2] / days of trial $\times 100\}$; feed efficiency ratio $($ FER $)$ = weight gain / total feed intake; protein productive value $(\mathrm{PPV}, \%)=[$ (final body weight $\times$ final whole-body protein (\% wet basis) - (initial body weight $\times$ initial whole-body protein $(\%$ wet basis $)$ ] / total protein intake; and energy productive value (EPV, $\%)=[($ final body weight $\times$ final whole-body energy $(\%$ wet basis) - (initial body weight $x$ initial whole-body energy (\% wet basis) $)]$ / total energy intake.

\section{Statistical analysis}

Results were previously tested for normality (ShapiroWilk test) and homoscedasticity of variances (Bartlett's test) and submitted to a three-way analysis of variance (ANOVA). Significant effects of the treatments were compared by Tukey's test $(P<0.05)$. All analyses were carried out in the software SAS v.9.1.

\section{RESULTS}

There was no significant effect of treatments (CF, DP, and DLC levels) and interaction among them on fish growth and survival rate (Table 2). DFI of fish decreased $(P<0.05)$ and FER increased $(P<0.05)$ with increasing dietary DP levels (Table 3 ). FER of fish was significantly affected by $\mathrm{CF} \times \mathrm{DP}$ interaction (Fig. 1). Additionally, there was a significant interaction between CF and DLC on DFI and FER (Fig. 2). Fish fed $100 \mathrm{CF} / 1 \mathrm{~g} \mathrm{~kg}^{-1}$ DLC diets increased $(P<0.05)$ feed intake. FER also was significantly affected by $\mathrm{CF} \times$ DLC interaction, in which increasing levels of $\mathrm{CF}$ without DLC supplementation resulted in a decrease $(P$ $<0.05)$ of feed efficiency of fish. FER of fish also was reduced $(P<0.05)$ by DLC supplementation when fish fed $100 \mathrm{~g} \mathrm{~kg}^{-1} \mathrm{CF}$.

Fish fed diets containing $290 \mathrm{~g} \mathrm{~kg}^{-1}$ of DP showed lower PPV $(P<0.05)$ than fish fed with the $250 \mathrm{~g} \mathrm{~kg}^{-1}$ DP diets. A significant triple interaction $(\mathrm{CF} \times \mathrm{DP} \times \mathrm{DLC})$ was registered on PPV (Table 3, Fig. 3). The DLC supplementation did not influence $(P>0.05)$ the PPV in any combination of $\mathrm{CF} \times \mathrm{DP}$. However, when DLC was supplemented and DP level increased in $100 \mathrm{~g} \mathrm{~kg}^{-1}$ $\mathrm{CF}$ diets, there was a reduction of PPV $(P<0.05)$. The same trend was registered when DP increased in unsupplemented diets and $150 \mathrm{~g} \mathrm{~kg}^{-1}$ of CF. On the other hand, EPV increased with carnitine supplementation $(P<0.05)$ and significantly decreased when dietary CF and DP levels increased, but no significant interaction of CF, DP, or DLC levels was registered on energy retention of fish.

The whole-body composition of Nile tilapia Oreochromis niloticus is shown (Table 4). Increasing dietary DP resulted in increased body protein contents $(P<0.05)$ and decreased moisture and lipid contents $(P$ $<0.05)$. On the other hand, increase CF from 100 to 150 $\mathrm{g} \mathrm{kg}^{-1}$ resulted in increased body lipid contents $(P<$ $0.05)$. There was a significant effect of DLC supplementation interacting with $\mathrm{CF}$ on whole-body protein and ash (Table 4, Fig. 4). Body protein decreased significantly due to DLC supplementation in fish fed with $150 \mathrm{~g} \mathrm{~kg}^{-1} \mathrm{CF}$ diets. However, no significant effect on body protein was registered in fish fed diets with the lowest CF level, regardless of dietary DLC supplementation. Whole-body ash as significantly reduced in fish fed $150 \mathrm{~g} \mathrm{~kg}^{-1} \mathrm{CF}$ and DLC supplemented.

\section{DISCUSSION}

As previously reported for other fish species, LC supplementation for tilapia also presented controversial results. Similar to this study, Nile tilapia Oreochromis niloticus fed diets supplemented with LC from $0.25 \mathrm{~g}$ $\mathrm{kg}^{-1}$ (Yang et al., 2009) to $1.0 \mathrm{~g} \mathrm{~kg}^{-1}$ (Erdogan et al., 2015) also presented no effects on growth parameters. On the other hand, supplementation of $0.15,0.50$, and $0.90 \mathrm{~g} \mathrm{~kg}^{-1} \mathrm{LC}$ increased weight gain, respectively, for hybrid tilapia (O. niloticus $\times O$. aureus) (Becker et al., 1999), Nile tilapia (Dikel et al., 2003) and Mozambique tilapia O. mossambicus (Jayaprakas et al., 1996).

Although the role of LC in fish growth is still unclear (Ma et al., 2008), its participation on mitochondrial fatty acids $\beta$-oxidation could improve the efficiency of diet energy utilization and proteinsparing effect resulting in better growth (Harpaz, 2005; Arslan, 2006; Mohseni \& Ozório, 2014). Contradictory results of carnitine supplementation on fish growth can be attributed to several factors, such as development stage of animals, diet composition, the relationship between LC and dietary lysine/methionine, experimental time and environmental conditions, supplementation level, possible leaching of carnitine in feed pellets, the chemoattractant action of carnitine, the stability of pellets and metabolic requirements of fish (Dias et al., 2001; Ozório et al., 2001b; Harpaz, 2005).

For instance, Becker et al. (1999), Dikel et al. (2003), and Jayaprakas et al. (1996) performed the experimental trial in intensive outdoor systems. In outdoor systems, fish are subjected to different sources of stress (e.g., xenobiotics, temperature variation, cyanotoxins) in which carnitine supplementation provided some protection (Harpaz et al., 1999; Schlechtriem 
Table 2. Growth performance of Nile tilapia fingerlings feeding dietary levels of crude fat (CF), digestible protein (DP), and DL-carnitine (DLC) for 74 days. FW: final weight, WG: weight gain, SGR: specific growth rate, SR: survival rate.

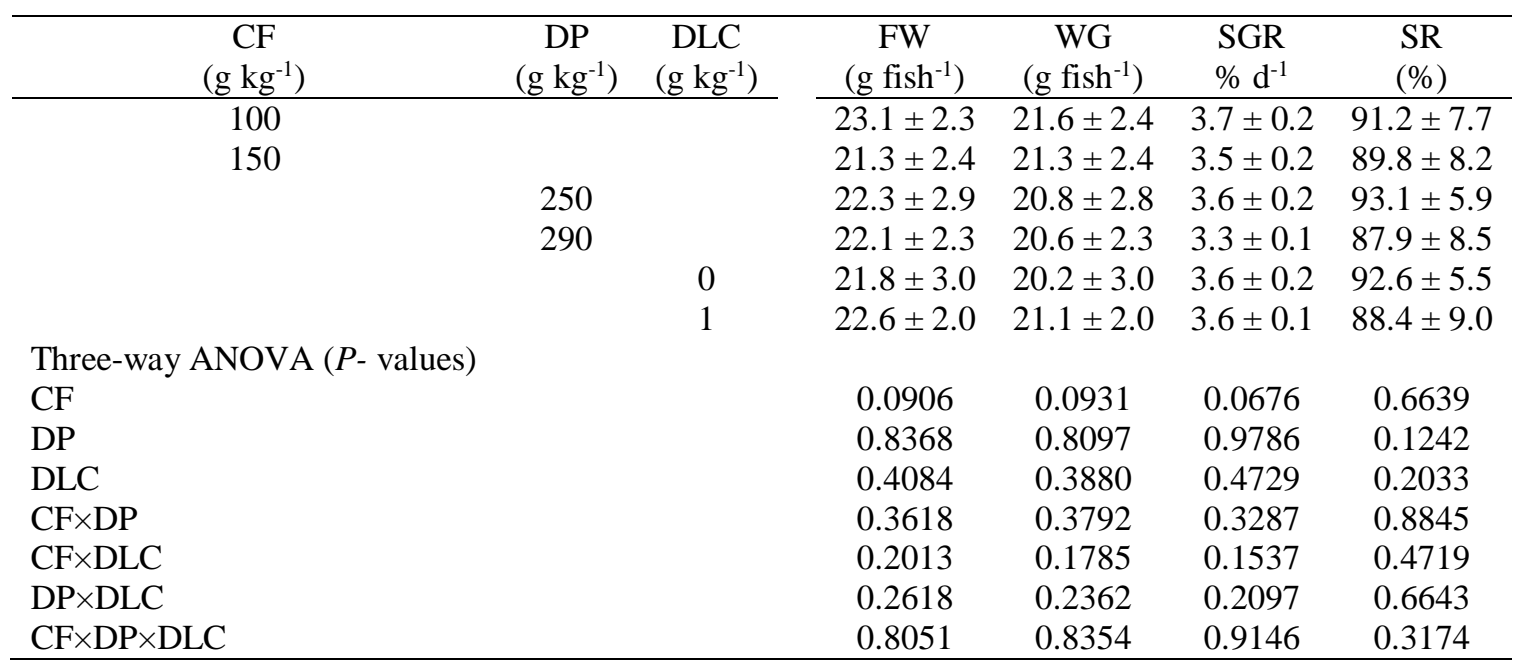

Table 3. Feed and nutrient utilization of Nile tilapia fingerlings feeding dietary levels of crude fat (CF), digestible protein (DP), DL-carnitine (DLC) for 74 days. DFI: daily feed intake (\% biomass $\left.\mathrm{d}^{-1}\right)$, FER: feed efficiency ratio, PPV: productive protein value (\%), EPV: productive energy value $(\%)$. Values in the same column with different superscript denote significant differences according to Tukey's test $(P<0.05)$.

\begin{tabular}{|c|c|c|c|c|c|c|}
\hline $\begin{array}{c}\mathrm{CF} \\
\left(\mathrm{g} \mathrm{kg}^{-1}\right)\end{array}$ & $\begin{array}{c}\mathrm{DP} \\
\left(\mathrm{g} \mathrm{kg}^{-1}\right)\end{array}$ & $\begin{array}{c}\text { DLC } \\
\left(\mathrm{g} \mathrm{kg}^{-1}\right)\end{array}$ & DFI & FER & PPV & EPV \\
\hline 100 & & & $3.33 \pm 0.17$ & $0.72 \pm 0.04$ & $28.6 \pm 1.6$ & $39.1 \pm 6.5^{\mathrm{a}}$ \\
\hline 150 & & & $3.33 \pm 0.09$ & $0.71 \pm 0.02$ & $29.0 \pm 1.9$ & $31.5 \pm 5.2^{\mathrm{b}}$ \\
\hline & 250 & & $3.38 \pm 0.11^{\mathrm{a}}$ & $0.70 \pm 0.02^{\mathrm{a}}$ & $30.0 \pm 1.1^{\mathrm{a}}$ & $39.7 \pm 5.9^{\mathrm{a}}$ \\
\hline & 290 & & $3.27 \pm 0.13^{\mathrm{b}}$ & $0.73 \pm 0.03^{\mathrm{b}}$ & $27.6 \pm 1.2^{\mathrm{b}}$ & $30.8 \pm 4.7^{\mathrm{b}}$ \\
\hline & & 0 & $3.29 \pm 0.13$ & $0.72 \pm 0.04$ & $28.9 \pm 1.5$ & $33.8 \pm 6.2^{\mathrm{a}}$ \\
\hline & & 1 & $3.37 \pm 0.13$ & $0.71 \pm 0.02$ & $28.7 \pm 1.9$ & $36.8 \pm 7.5^{\mathrm{b}}$ \\
\hline \multicolumn{7}{|c|}{ Three-way ANOVA ( $P$ - values) } \\
\hline $\mathrm{CF}$ & & & 0.9558 & 0.1594 & 0.3605 & $<.0001$ \\
\hline DP & & & 0.0228 & 0.0060 & $<.0001$ & $<.0001$ \\
\hline DLC & & & 0.1080 & 0.0760 & 0.1463 & 0.0502 \\
\hline $\mathrm{CF} \times \mathrm{DP}$ & & & 0.1312 & 0.0223 & 0.1183 & 0.4505 \\
\hline $\mathrm{CF} \times \mathrm{DLC}$ & & & 0.0285 & 0.0094 & 0.7498 & 0.9230 \\
\hline $\mathrm{DP} \times \mathrm{DLC}$ & & & 0.5209 & 0.0511 & 0.0594 & 0.4336 \\
\hline $\mathrm{CF} \times \mathrm{DP} \times \mathrm{DLC}$ & & & 0.3013 & 0.5360 & 0.0155 & 0.9552 \\
\hline
\end{tabular}

et al., 2004; Guzmán-Guillén et al., 2013). On the other hand, this trial was performed in controlled and ideal conditions, without stressful factors and in this case, no effect of dietary DLC supplementation on fish growth was observed, in accordance to Akbari et al. (2014).

Fish consume feed to meet their energy requirements, and consequently, the concentration of this nutrient in formulated diet limits feed intake. In this trial, fish fed diets containing $100 \mathrm{~g} \mathrm{~kg}^{-1} \mathrm{CF}$ meet the minimum DE requirement, according to NRC (2011). However, Nile tilapia can make adjustments in their consumption, even at energy concentrations slightly above or below the minimum nutritional requirement (Fortes-Silva \& Sánchez-Vázquez, 2012). In this case, DLC supplementation in $100 \mathrm{~g} \mathrm{~kg}^{-1} \mathrm{CF}$ diets stimulated fish feed intake to metabolize the substrate to perform the $\beta$-oxidation due to the increased levels of circulating LC. It should be noted that feed intake of fish fed $150 \mathrm{~g} \mathrm{~kg}^{-1} \mathrm{CF}$ diets was not different regardless of carnitine supplementation (Fig. 2).

There is a close relationship between dietary LC, lipids levels, and body LC concentration in fish (Gaylord \& Gatlin, 2000; Ozório et al., 2001a). For example, Ozório et al. (2010) recorded an increase of 


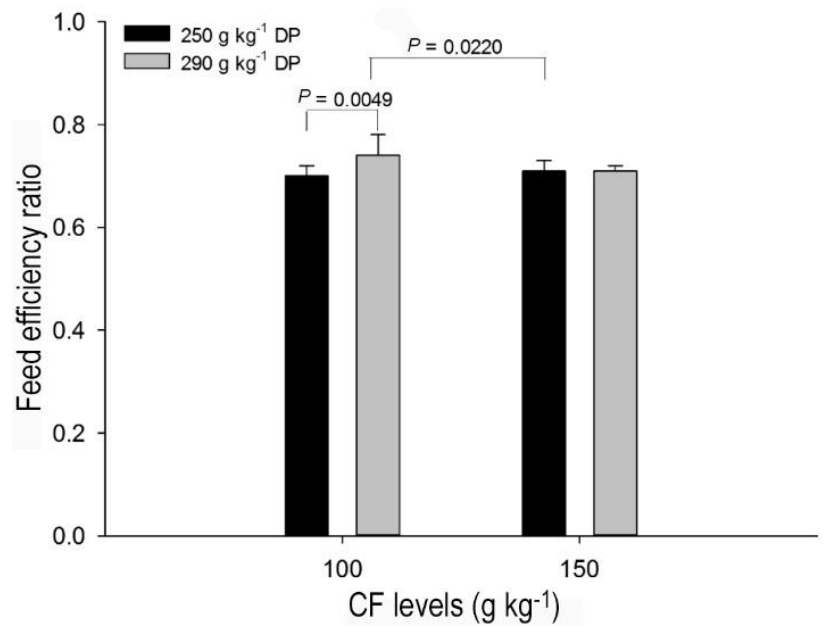

Figure 1. Interaction between dietary crude fat $(\mathrm{CF})$ and digestible protein (DP) levels on feed efficiency ratio of Nile tilapia juveniles. Bars show the significant differences with respective $P$ values between these factors.

$30 \%$ in muscle and plasma carnitine levels in African catfish Clarias gariepinus when dietary lipid increased from 100 to $180 \mathrm{~g} \mathrm{~kg}^{-1}$. The LC circulating in the body is a combination of supplemental sources, through biosynthesis and reabsorption rates (Rebouche \& Seim, 1998). In the present study, when lipid content increased in DLC-unsupplemented diets, it was observed a reduction in feed efficiency (Fig. 2). Additionally, it was registered a decrease in FER when $100 \mathrm{~g} \mathrm{~kg}^{-1} \mathrm{CF}$ diets were supplemented with DLC (Fig. $2)$. These results suggest that endogenous LC concentration in Nile tilapia juveniles was not enough to oxidize dietary lipid content. Gaylord \& Gatlin (2000) reported variations in muscle concentrations of LC of striped bass $\times$ white bass hybrids (Morone saxatilis $\times$ M. chrysops) supplemented with $3.0 \mathrm{~g} \mathrm{~kg}^{-1}$ LC diet as a function of the dietary lipid content (5 and $20 \%$ ).

The mechanism by which this occurs is still unclear. However, Ozório et al. (2010) concluded that the diet's lipid level could influence the transport and use of LC. Therefore, LC concentrations required to improve feed efficiency may be directly linked to the $\mathrm{CF}$ concentration of the diet, corroborating the observations of Torreele et al. (1993), Ozório et al. (2001a) and Jalali-Haji-Abadi et al. (2010). Moreover, the decrease feed efficiency herein observed in fish fed DLC at $100 \mathrm{~g} \mathrm{~kg}^{-1} \mathrm{CF}$ diets can be explained by additional energy expenditure due to excessive circulating LC that was not used in the $\beta$-oxidation of the fatty acids.

The whole-body protein retention rate decreased when dietary DP was increased from 250 to $290 \mathrm{~g} \mathrm{~kg}^{-1}$. Therefore, it was observed that dietary DP reduced

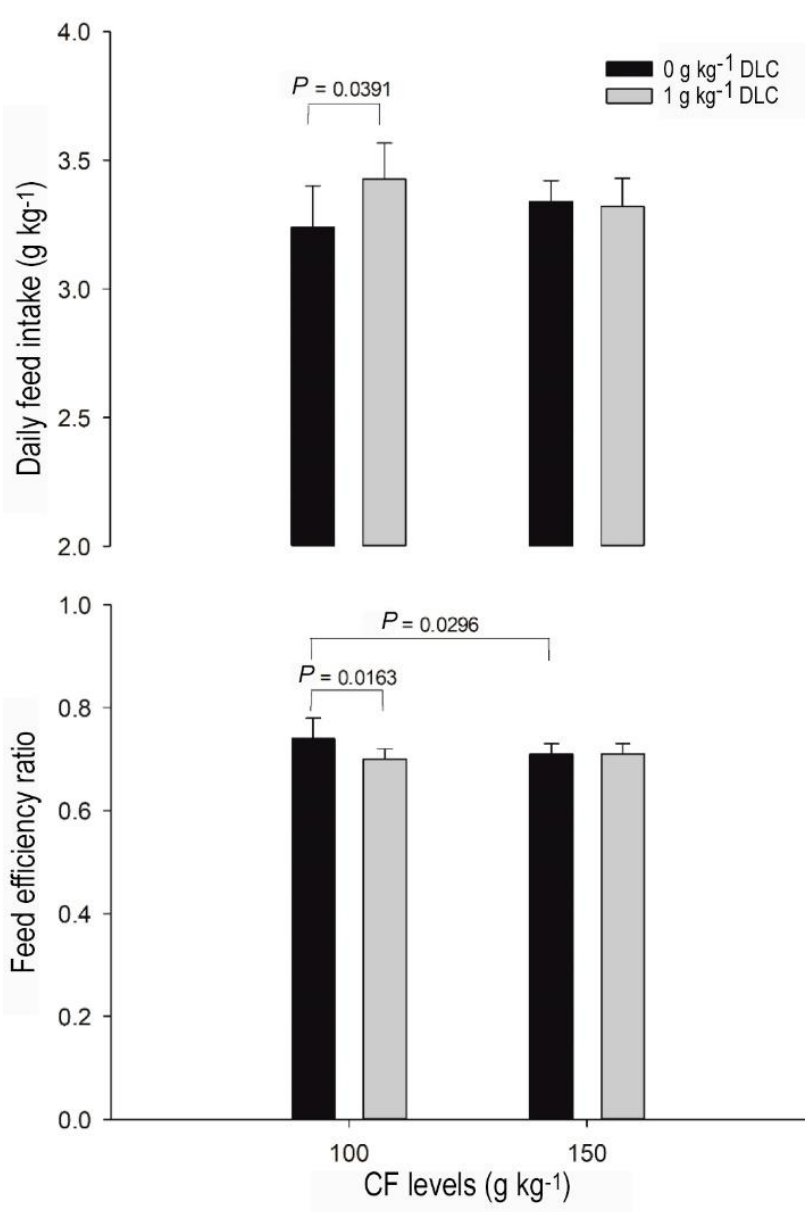

Figure 2. Interaction between dietary crude fat $(\mathrm{CF})$ and DL-carnitine (DLC) levels on intake and use of feed by Nile tilapia juveniles. Bars show the significant differences with respective $P$ values between these factors.

whole-body protein retention, indicating that $250 \mathrm{~g} \mathrm{~kg}^{-1}$ was sufficient to meet fish protein requirements and, that $290 \mathrm{~g} \mathrm{~kg}^{-1}$ of dietary DP provided protein excess. These results suggest that excess protein intake from the diet can reduce the efficiency of protein utilization by fish and decreased growth. When dietary amino acids are not utilized to protein synthesis, it deviates as an energy source, lipogenesis or gluconeogenesis.

The present study used DLC as a source of a biologically active form of carnitine (LC). An important aspect of supplementation of $\mathrm{LC}$ in aquafeeds is the high price of purified levocarnitine form, once effective levels to increase fish growth are 10-15 times higher than preconized for poultry (Golzar-Adabi et al., 2011). Becker et al. (1999) suggested that dietary supplementation over $0.15 \mathrm{~g} \mathrm{~kg}^{-1}$ of $\mathrm{LC}$ for tilapia is economically infeasible. Therefore, Harpaz (2005) recommended a cost/benefit analysis when LC is included in fish diets. On the other hand, DLC is near ten times low cost than pure LC form and, probably due 


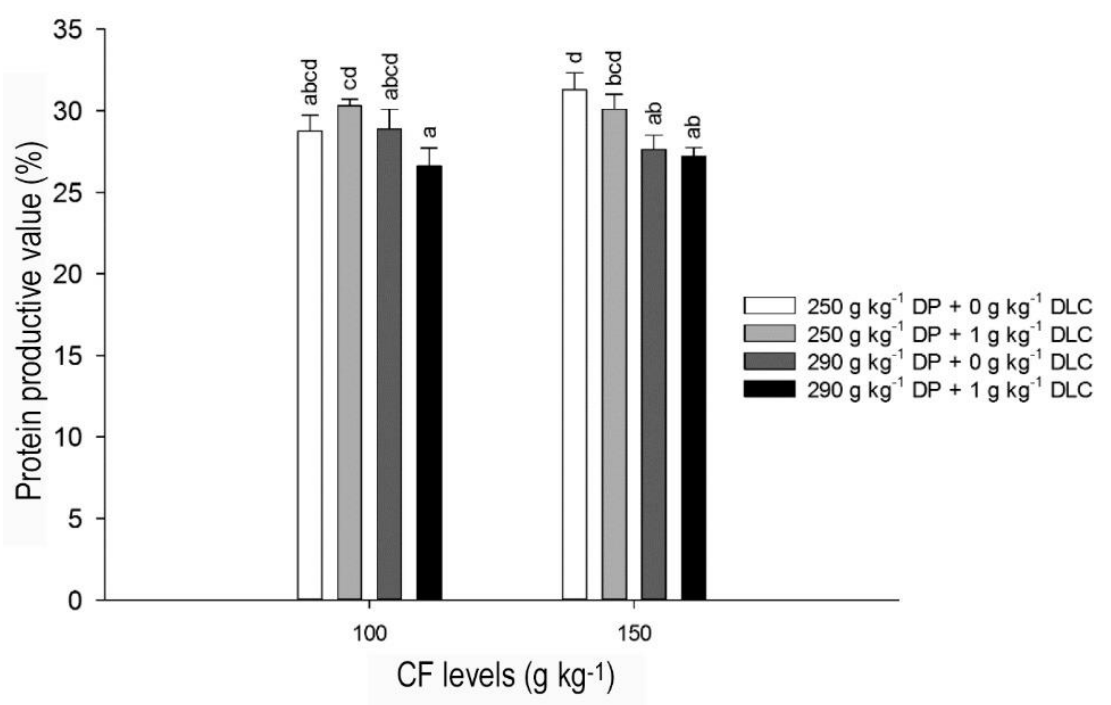

Figure 3. Interaction between dietary crude fat (CF), digestible protein (DP) DL-carnitine (DLC), and levels on protein retention by Nile tilapia juveniles. Different lowercases show significant $(P<0.05)$ differences by Tukey's test.

Table 4. Whole-body composition (wet basis) of Nile tilapia fingerlings feeding dietary levels of crude fat (CF), digestible protein (DP), and DL-carnitine (DLC) for 74 days. Values in the same column with different superscript denote significant differences according to Tukey's test $(P<0.05)$.

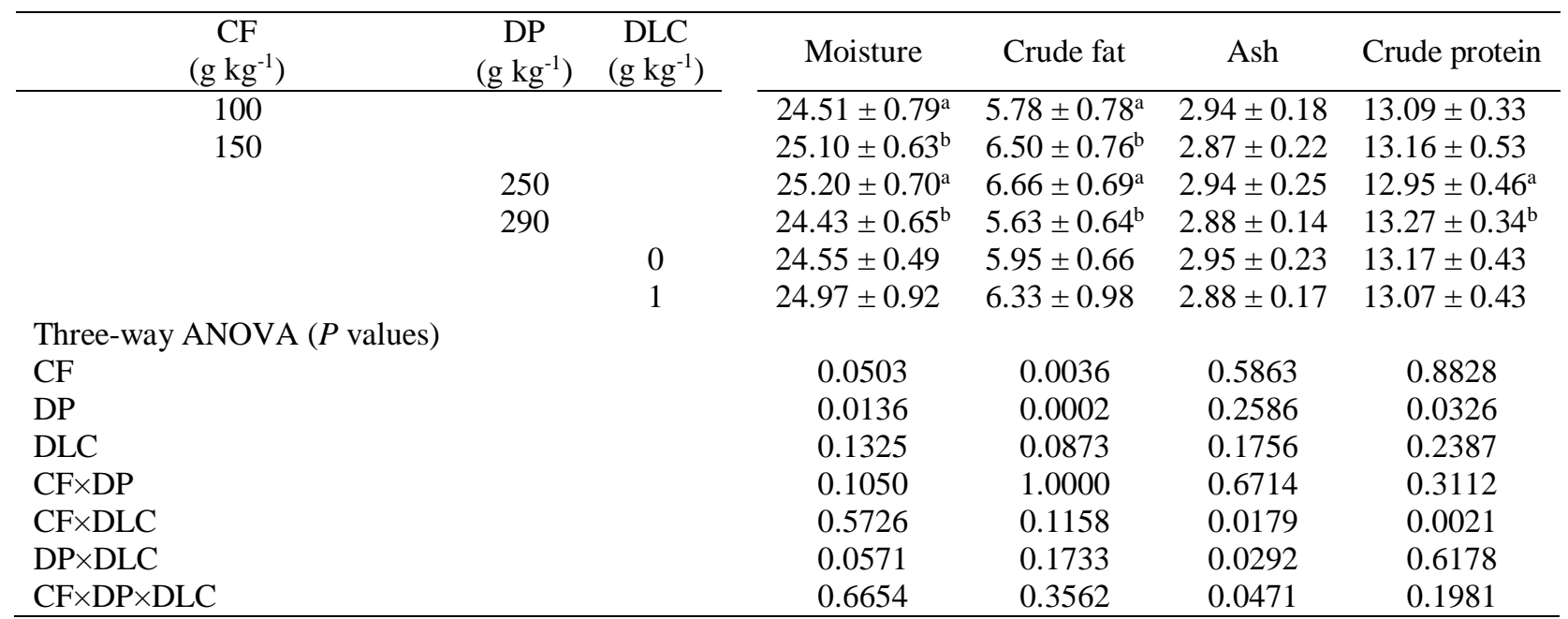

to this feature, has been used in several pharmaceutical formulations and food supplements commercialized in different countries (Lopes et al., 2004; SánchezHernández et al., 2010a,b).

According to Rebouche \& Seim (1998), D-isomer competitively inhibits the carnitine acetyltransferase activity and, consequently, decreases the oxidation of fatty acids and the mitochondrial transport of long fatty acids. On the other hand, LC is assimilated in the intestine 1.6 to 2.0 times faster than the D-form (Gross \& Henderson, 1984). Thus, the increase in EPV in fish fed DLC-diets shown a slight but effective biological effect of DLC on lipid metabolism, as reported by Silva et al. (2018).

Fish body and muscle lipid content can be reduced by LC supplementation due to its role in the oxidation of fatty acids (Harpaz, 2005). Additionally, LC supplementation provides an increase in body protein and muscle content (Keshavanath \& Renuka, 1998). This typical response from the body and muscle composition by dietary LC supplementation has been observed in some fat fish, such as rohu (Labeo rohita) (Keshavanath \& Renuka, 1998) and mrigal carp (Cirrhinus cirrhosus) (Singh et al., 2008). 


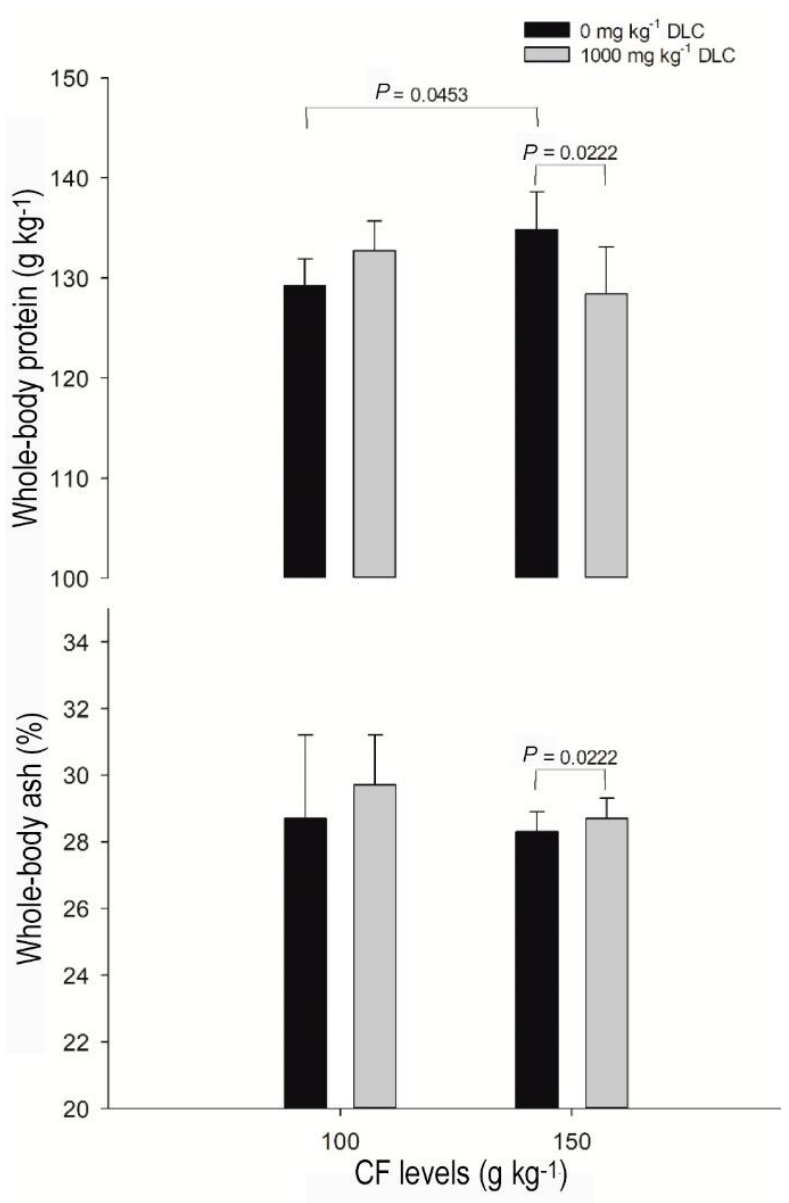

Figure 4. Interaction between dietary crude fat $(\mathrm{CF})$ and DL-carnitine (DLC) levels on whole-body protein and ash contents of Nile tilapia juveniles. Bars show the significant differences with respective $P$-values between these factors.

In this trial, the whole-body lipid of the Nile tilapia juveniles was only influenced by the dietary CF and DP concentrations. Considering that the muscles are the main storage site of LC (Harpaz, 2005), Jalali-HajiAbadi et al. (2010) hypothesized that the determination of muscle lipids in fat considered fish would be a better indicator of the lipid oxidation than the body fat. However, the Nile tilapia is considered a lean-meat species from the human consumption viewpoint (Jobling, 2001), and at first, there are no reasons for differences in the effect of DLC on the composition of the muscle and whole-body lipid. Besides, no effect of LC supplementation has been recorded on the chemical composition of other species (Berger \& Sachan, 1991; Gaylord \& Gatlin, 2000; Twibell \& Brown, 2000; Dias et al., 2001). Thus, as previously described for growth performance, the effects of LC supplementation on the body chemical composition of fish are still unclear, at least, contradictory.
In conclusion, dietary LC supplementation using DLC as a source did not improve the growth of Nile tilapia juveniles. Additionally, despite the LC source used in the present study, it was demonstrated a strong interaction between DLC and CF levels on several parameters related to feed and nutrient use. Thus, further studies are recommended to investigate the interaction between DLC and CF, aiming to determine an ideal dietary $\mathrm{CF}: \mathrm{LC}$ ratio.

\section{ACKNOWLEDGEMENT}

The authors are indebted to Conselho Nacional de Desenvolvimento Cientifico e Tecnológico (National Council of Scientific and Technological Development - CNPq; grant No477105/2012-2) and Fundação de Amparo a Ciência e Tecnologia do Estado de Pernambuco (Pernambuco State Foundation for Science and Technology Support - FACEPE; grant $\mathrm{N}^{\circ}$ APQ-0882-5.06) for providing the financial support for this study. In addition, authors are indebted with FACEPE by Master scholarships granted to S.C. (PBPG-0407-5.06/11). The authors also would like to thank Companhia de Desenvolvimento do Vale do São Francisco e Parnaíba (São Francisco and Parnaíba Valleys Development Company-CODEVASF; Porto Real do Colégio, AL, Brasil) for providing the Nile tilapia fingerlings.

\section{REFERENCES}

Akbari, M., Rahimabadi, E.Z., Sorinejad, I., Rad, M.A., Efatpanah, E. \& Khanjani, M.H. 2014. Effect of different levels of dietary L-carnitine on growth performance, food efficiency and body composition of pikeperch (Sander lucioperca) fingerlings world. Journal of Fish and Marine Sciences, 6: 227-232.

Arslan, C. 2006. L-carnitine and its use as a feed additive in poultry feeding a review. Revue de Médecine Vétérinaire, 157: 134-142.

Association of Official Analytical Chemists (AOAC). 1990. Official methods of analysis. AOAC, Virginia.

Becker, K., Schreiber, S., Angoni, C. \& Blum, R. 1999. Growth performance and feed utilization response of Oreochromis niloticus $\times$ Oreochromis aureus hybrids to L-carnitine measured over a full fattening cycle under commercial conditions. Aquaculture, 174: 313322.

Berger, R. \& Sachan, D.S. 1991. Effects of supplementary levels of L-carnitine on blood and urinary carnitines and on the portal-systemic blood-ethanol concentrations in the rat. Journal of Nutritional Biochemistry, 2: $382-386$. 
Bilinski, E. \& Jonas, R.E.E. 1970. Effects of coenzyme a and carnitine on fatty acid oxidation by rainbow trout mitochondria. Journal of the Fisheries Research Board of Canada, 27: 857-864.

Chatzifotis, S., Takeuchi, T. \& Seikai, T. 1995. The effect of dietary L-carnitine on growth performance and lipid composition in red sea bream fingerlings. Fisheries Science, 61: 1004-1008.

De Silva, S.S., Gunasekera, R.M. \& Shim, K.F. 1991. Interactions of varying dietary protein and lipid levels in young red tilapia: evidence of protein sparing. Aquaculture, 95: 305-318.

Demarquoy, J., Georges, B., Rigault, C., Royer, M.-C., Clairet, A., Soty, M., Lekounoungou, S. \& Le Borgne, F. 2004. Radioisotopic determination of L-carnitine content in foods commonly eaten in western countries. Food Chemistry, 86: 137-142.

Dias, J., Arzel, J., Corraze, G. \& Kaushik, J. 2001. Effects of dietary L-carnitine supplementation on growth and lipid metabolism in European seabass (Dicentrarchus labrax). Aquaculture Research, 32: 206-215.

Dikel, S., Alev, M.V., Kiris, G.A. \& Çelík, M. 2003. Effects of supplemental dietary L-carnitine on the growth of Nile tilapia (Oreochromis niloticus) in cage conditions. Turkish Journal of Veterinary and Animal Sciences, 27: 663-669.

Dikel, S., Ünalan, B., Eroldoğan, O.T. \& Özlüer Hunt, A. 2010. Effects of dietary L-carnitine supplementation on growth, muscle fatty acid composition and economic profit of rainbow trout (Oncorhynchus mykiss). Turkish Journal of Fisheries and Aquatic Sciences, 10: 173-180.

Erdogan, F., Kanyilmaz, M., Aydin, B., Erdogan, M., Aksoy, A. \& Gumus, E. 2015. Effect of dietary supplementation of L-carnitine on growth, feed utilization and liver histology in Nile tilapia Oreochromis niloticus (Linnaeus, 1758) fry. Indian Journal of Fisheries, 62: 123-127.

Fortes-Silva, R. \& Sánchez-Vázquez, F.J. 2012. Use of self-feeders to evaluate macronutrient self-selection and energy intake regulation in Nile tilapia. Aquaculture, 326-329: 168-172.

Furuya, W.M., Pezzato, L.E., Barros, M.M., Boscolo, W.R., Cyrino, J.E.P., Furuya, V.R.B. \& Feiden, A. 2010. Tabelas brasileiras para a nutrição de tilápias. GFM, Toledo.

Gaylord, T.G. \& Gatlin, D.M. 2000. Dietary lipid level but not L-carnitine affects growth performance of hybrid striped bass (Morone chrysops $+\times$ M. saxatilis $\delta^{\Uparrow}$ ). Aquaculture, 190: 237-246.

Golzar-Adabi, S., Cooper, R.G., Ceylan, N. \& Corduk, M. 2011. L-carnitine and its functional effects in poultry nutrition. World's Poultry Science Journal, 67: 277296.
Gross, C.J. \& Henderson, L.M. 1984. Absorption of d- and L-carnitine by the intestine and kidney tubule in the rat. Biochimica et Biophysica Acta (BBA) Biomembranes, 772: 209-219.

Guzmán-Guillén, R., Prieto, A.I., Vázquez, C.M., Vasconcelos, V. \& Cameán, A.M. 2013. The protective role of 1-carnitine against cylindrospermopsininduced oxidative stress in tilapia (Oreochromis niloticus). Aquatic Toxicology, 132-133: 141-150.

Harpaz, S. 2005. L-carnitine and its attributed functions in fish culture and nutrition - a review. Aquaculture, 249: $3-21$.

Harpaz, S., Becker, K. \& Blum, R. 1999. The effect of dietary L-carnitine supplementation on cold tolerance and growth of the ornamental cichlid fish Pelvicachromis pulcher - preliminary results. Journal of Thermal Biology, 24: 57-62.

Jalali-Haji-Abadi, S.M.A., Mahboobi-Soofiani, N., Sadeghi, A.A., Chamani, M. \& Riazi, G.H. 2010. Effects of supplemental dietary L-carnitine and ractopamine on the performance of juvenile rainbow trout, Oncorhynchus mykiss. Aquaculture Research, 41: 1582-1591.

Jayaprakas, V., Sambhu, C., Kumar, S.S. \& Sunil-Kumar, S. 1996. Effect of dietary L-carnitine on growth and reproductive performance of male Oreochromis mossambicus (Peters). Fishery Technology, 33: 84-90.

Jobling, M. 2001. Nutrient repartitioning and the influence of feed composition on body composition In: Houlihan, D., Boujard, T. \& Jobling, M. (Eds.). Food intake in fish. Blackwell Publishing, Oxford, pp. 354375.

Keshavanath, P. \& Renuka, P. 1998. Effect of dietary Lcarnitine supplements on growth and body composition of fingerling rohu, Labeo rohita (Hamilton). Aquaculture Nutrition, 4: 83-87.

Lim, C., Yildirim-Aksoy, M. \& Klesius, P. 2011. Lipid and fatty acid requirements of tilapias. North American Journal of Aquaculture, 73: 188-193.

Lopes, G., Gazola, V.A.F.G., Galende, S.B., Alves-doPrado, W., Curi, R. \& Bazotte, R.B. 2004. Comparative acute effects of L-carnitine and DL-carnitine on hepatic catabolism of L-alanine and L-glutamine in rats. Acta Pharmacologica Sinica, 25: 1257-1261.

Lu, D.-L., Limbu, S.M., Lv, H.-B., Ma, Q., Chen, L.-Q., Zhang, M.-L. \& Du, Z.-Y. 2019. The comparisons in protective mechanisms and efficiencies among dietary $\alpha$-lipoic acid, $\beta$-glucan, and L-carnitine on Nile tilapia infected by Aeromonas hydrophila. Fish and Shellfish Immunology, 86: 785-793.

Ma, J.J., Xu, Z.R., Shao, Q.J., Xu, J.Z., Hung, S.S.O., Hu, W.L. \& Zhuo, L.Y. 2008. Effect of dietary supplemental L-carnitine on growth performance, body composition and antioxidant status in juvenile 
black sea bream, Sparus macrocephalus. Aquaculture Nutrition, 14: 464-471.

Mohseni, M. \& Ozório, R.O.A. 2014. Effects of dietary Lcarnitine level on growth performance, body composition and antioxidant status in beluga (Huso huso L. 1758). Aquaculture Nutrition, 20: 477-485.

Naz, M., Yilmaz, E. \& Türkmen, M. 2005. A preliminary study on African catfish (Clarias gariepinus) larvae fed with diets containing different $\mathrm{E} / \mathrm{P}$ ratios and Lcarnitine supplementation. Journal of Animal and Veterinary Advances, 4: 871-875.

National Research Council (NRC). 2011. Nutrients requirements of fish and shrimp. The National Academies Press, Washington, DC.

Ozório, R.O.A., Booms, G.H.R., Huisman, E.A. \& Verreth, J.A.J. 2002. Changes in amino acid composition in the tissues of African catfish (Clarias gariepinus) as a consequence of dietary L-carnitine supplements. Journal of Applied Ichthyology, 18: 140147.

Ozório, R.O.A., Uktoseja, J.L.A., Huisman, E.A. \& Verreth, J.A.J. 2001a. Changes in fatty acid concentrations in tissues of African catfish, Clarias gariepinus Burchell, as a consequence of dietary carnitine, fat and lysine supplementation. British Journal of Nutrition, 86: 623-636.

Ozório, R.O.A., Van Eekeren, T.H.B., Huisman, E.A. \& Verreth, J.A.J. 2001b. Effects of dietary carnitine and protein energy:nonprotein energy ratios on growth, ammonia excretion and respiratory quotient in African catfish, Clarias gariepinus (Burchell) juveniles. Aquaculture Research, 32: 406-414.

Ozório, R.O.A., Escorcio, C., Bessa, R.J.B., Ramos, B. \& Gonçalves, J.F.M. 2012. Comparative effects of dietary 1-carnitine supplementation on diploid and triploid rainbow trout (Oncorhynchus mykiss). Aquaculture Nutrition, 18: 189-201.

Ozório, R.O.A., Van Ginneken, V.J.T., Bessa, R.J.B., Verstegen, M.W.A., Verreth, J.A.J. \& Huisman, E.A. 2010. Effects of exercise on L-carnitine and lipid metabolism in African catfish (Clarias gariepinus) fed different dietary L-carnitine and lipid levels. British Journal of Nutrition, 103: 1139-1150.

Rebouche, C.J. \& Seim, H. 1998. Carnitine metabolism and its regulation in microorganisms and mammals. Annual Review of Nutrition, 18: 39-61.

Rodrigues, M.L., do Santos, M.S., Damasceno, D.Z., Pessini, J.E. \& Bittencourt, F. 2019. Supplementation of L-carnitine in diets for silver catfish and its effects on reproductive aspects. Boletim do Instituto de Pesca, 45(1): 409.

Rostagno, H.S., Albino, L.F.T., Donzele, J.L., Gomes, P.C., Oliveira, R.F., Lopes, D.C., Ferreira, A.S., Barreto, S.L.T. \& Euclides, R.F. 2011. Tabelas brasileiras para aves e suínos: composição de alimentos e exigências nutricionais de aves e suínos. Universidade Federal de Viçosa, Viçosa.

Sánchez-Hernández, L., García-Ruiz, C., Crego, A.L. \& Marina, M.L. 2010b. Sensitive determination of dcarnitine as enantiomeric impurity of levocarnitine in pharmaceutical formulations by capillary electrophoresis-tandem mass spectrometry. Journal of Pharmaceutical and Biomedical Analysis, 53: 12171223.

Sánchez-Hernández, L., Castro-Puyana, M., García-Ruiz, C., Crego, A.L. \& Marina, M.L. 2010a. Determination of L- and D-carnitine in dietary food supplements using capillary electrophoresis-tandem mass spectrometry. Food Chemistry, 120: 921-928.

Santulli, A. \& D'Amelio, V. 1986. Effects of supplemental dietary carnitine on growth and lipid metabolism of hatchery-reared sea bass (Dicentrarchus labrax L.). Aquaculture, 59: 177-186.

Schlechtriem, C., Bresler, V., Fishelson, L., Rosenfeld, M. \& Becker, K. 2004. Protective effects of dietary 1carnitine on tilapia hybrids (Oreochromis niloticus $\mathrm{x}$ Oreochromis aureus) reared under intensive pondculture conditions. Aquaculture Nutrition, 10: 55-63.

Schuhmacher, A. \& Gropp, J.M. 1998. Carnitine - a vitamin for rainbow trout? Journal of Applied Ichthyology, 14: 87-90.

Selcuk, Z., Tiril, S.U., Alagil, F., Belen, V., Salman, M., Cenesiz, S., Muglali, O.H. \& Yagci, F.B. 2010. Effects of dietary L-carnitine and chromium picolinate supplementations on performance and some serum parameters in rainbow trout (Oncorhynchus mykiss). Aquaculture International, 18: 213-221.

Silva, F.M., Ferreira, M.L.S., Cavalcante-Lucena, J.E. \& Bicudo, A.J.A. 2018. DL-carnitine as supplementary levocarnitine source in plant-based diets to Nile tilapia (Oreochromis niloticus) fingerlings. Latin American Journal of Aquatic Research, 46: 825-830.

Singh, R.K., Desai, A.S., Chavan, S.L. \& Khandagale, P.A. 2008. Effects of varying concentrations of Lcarnitine-incorporated diets on growth and body composition of fry of Cirrhinus mrigala (Hamilton, 1822). Journal of the World Aquaculture Society, 39: 275-280.

Stickney, R.R. \& Hardy, R.W. 1989. Lipid requirements of some warm-water species. Aquaculture, 79: 145156.

Torreele, E., Sluiszen, A. \& Verreth, J. 1993. The effect of dietary L-carnitine on the growth performance in fingerlings of the African catfish (Clarias gariepinus) in relation to dietary lipid. British Journal of Nutrition, 69: 289-299.

Twibell, R.G. \& Brown, P.B. 2000. Effects of dietary carnitine on growth rates and body composition of 
hybrid striped bass (Morone saxatilis male $\times M$. chrysops female). Aquaculture, 187: 153-161.

Wang, Q., Luo, S., Ghonimy, A., Chen, Y., Guo, Z., Liu, H. \& Zhang, D. 2019. Effect of dietary L-carnitine on growth performance and antioxidant response in Amur minnow (Phoxinus lagowskii Dybowskii). Aquaculture Nutrition, 25(4): 749-760.

Received: 15 January 2020; Accepted: 5 May 2020
Yang, S., Wen, Y., Liou, C.-H. \& Liu, F. 2009. Influence of dietary L-carnitine on growth, biological traits and meat quality in tilapia. Aquaculture Research, 40: 1374-1382. 